\title{
The Impact Of ICT's In Education: The Case Of University Of Macedonia Students
}

Areti Valasidou, University of Macedonia, Greece

Despoina Bousiou-Makridou, University of Macedonia, Greece

\begin{abstract}
The aim of this paper is to describe the results of a research that took place in order to examine the opinion and impact of Information and Communication Technology to undergraduate students of University of Macedonia. The research was conducted with two main purposes. The first purpose is to investigate how familiar are the students of international and political studies with the use of ICT's on and off campus. The second purpose of the research is to examine the possible relationship between the use of ICT's and the gender and the students' performance (marks) at the "Introduction to Computers" module that is part of their programme of studies. The results revealed that male students are more favourable toward ICT usage and the students that scored high at the module "Introduction to Computers" were more likely to find that the use of ICT's help them at their studies with various ways. The university academic and administrative personnel is highly recommended to find ways in order the students to be motivated and maintain positive students attitudes to use ICT's. Thus, the students will find it very helpful during their studying or even a supplement to other teaching activities.
\end{abstract}

\section{INTRODUCTION}

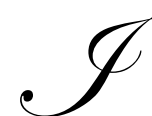

nformation and Communication Technologies (ICTs) are generally accepted as a modern instrumental tool that enables the educators to modify the teaching methods they use in order to increase the students interest. The extended use of ICTs drove the society into a new knowledge -based form where information plays an important role for the universities enlargement and students satisfaction (Xin, 1999).

Hoffman (2001) suggested that successful implementation of ICTs need to address five interlocking frameworks for change: the infrastructure, attitude, staff development, support (technical and administrative) and also sustainability and transferability.

There are different kinds of ICTs implemented at teaching and learning such as tele and video-conferencing and e-leanirng tools. These products can be used in education for different purposes. Some of them help students with their learning by improving the communication between them and the instructors (Valasidou and Bousiou, 2005).

Based on the extended usage of ICTs in education the need appeared to determine the level of the impact of ICTs to the undergraduate students of the University of Macedonia, Greece. The present paper aims to examine how familiar are the students of international and political sciences with the ICTs use. The research conducted also aims to reveal the possible relationship between the use of ICTs and the gender and students performance.

\section{LITERATURE REVIEW}

There are many studies conducted the past years concerning ICTs usage in education. According to Dorup (2004) the majority of medical students in Denmark had access to computers at home as well as used e-mail and the 
internet regularly. Only a few students prefer not to use computers at home. Finally, the research revealed that students believe that the use of ICTs cannot replace the traditional teaching activities but it can be easily used as a supplement.

Another study, contacted by Siritongthaworn et al (2006) examined the e-learning technology implementation of universities in Thailand. According to the findings the students were used to instruction in the structured format due to the traditional norms of education. The key issue for thai universities is to persuade students and instructors to use ICT's effectively and motivate them to integrate them to the learning and teaching procedures respectively.

In terms of gender Gay and Blades (2005) recommend academicians and course administrators to pay more attention to the use of ICT's resources as a major component in classroom teaching. Females, to a larger degree than males reported that they had access to a computer off campus.

Another survey conducted by Schumacher and MorahanMartin (2001) argued that females are less experienced with ICT's and are more likely than males to have negative attitudes towards computers. Furthermore, male students prefer to study to courses that require computer use more than female students and show interest in programming and games playing. They are also more experienced at the ICT's use than girls, apart from e-mails where no significant differences were reported. Moreover, Shashaani (1997) examined some males and females about their interest in internet use and discovered that there was a great difference on the interest level between the two groups. Male respondents showed to be more interested in internet services and use towards women.

Similar results about the internet and computer usage between males and females were revealed by other studies as well. Although women and men show little difference in general attitudes toward internet, there were many differences toward internet searching and usage. Ford and Miller (1996) suggest that women are more likely to report significantly greater levels of disorientation and disenchantment in relation to internet, compared to males. MorahanMartin (1999) found that women college students get internet access less often, spend less time online and don't surf for different purposes as often as men.

Another issue that needs to be examined regarding the ICTs usage of students is the effect on their performance. Kulik's (1994) meta-analysis study revealed that on average, students who used computer-based instruction scored higher students without computers. The students also learn more in less time and they like their classes more when computer-based instruction was included.

Silvin-Kachala's (1998) analysis pointed out that students in technology rich environment experienced positive effects on achievement in all major subject areas. Furthermore, their attitudes toward learning and their own self-concept improved consistently when computers were used for instruction.

The following session describes the research that was conducted in order to examine whether there were differences in gender referring the ICT's usage in university students. Moreover, there was some research about the possible relationship between the computers and internet usage and the students' performance.

\section{METHOD OF RESEARCH}

The research can be divided into two main parts: the first part includes the research questions that attempt to investigate how familiar are the students of international and political studies with the use of ICTs on and off campus. The second part of the research examines the possible relationship between the use of ICTs and the gender as well as the students performance on the computers module.

The following research questions where examined:

1. Do students use ICTs to support their studies?

2. What are the students attitudes toward Information Technology? 
3. Does gender impact on the use of ICTs?

4. Is students performance affected by their ICTs usage?

The sample of the research was chosen from the undergraduate students in the Department of Political and International Studies at the University of Macedonia. The research sample was consisted from 190 students (the overall number of $1^{\text {st }}$ year students) and a questionnaire was distributed to them in order to complete it.

The questionnaire was divided into three main areas. The first part of the questionnaire sought demographic characteristics of the respondents in the sample. One hundred and thirty five usable responses were obtained, resulting in $71 \%$ response rate.

The second part of the questionnaire focused on the students knowledge and experience of using ICTs on and off campus. This area attempted to examine whether the respondents have internet access off campus, whether they use e-mail, chatting or other internet tools and finally whether they visit often the university lab to support their studies.

The last part of the questionnaire derived information about students' attitudes to computer use, which were dichotomously scored ("yes" or "no").

In terms of data analysis, the first two research questions were answered by using descriptive statistics. For research questions 3 and 4, Pearson chi square analysis was conducted to examine the effect of gender on ICTs usage and the effect of ICTs usage on students performance.

\section{FINDINGS AND DISCUSSION}

According to the findings of the research (see Table 1) the students of University of Macedonia use compus (an e-learning tool) to get information for their modules and visit the university lab very often. Siritongthaworn et al (2006) agreed with these results and pointed out that there should be the appropriate technical help by the administrative faculty in order the students to exploit effectively the ICT's developments.

\section{Table 1: ICT's support of students}

\begin{tabular}{|c|c|c|}
\hline & Yes \% & No $\%$ \\
\hline I use compus to get information for my modules & 84 & 16 \\
\hline I visit the university lab to support my studies & 67 & 33 \\
\hline
\end{tabular}

Table 2 shows that students have a very positive attitude towards information technology. The respondents use ICT's to write their assignments (93\%), to send e-mail to the teacher $(64 \%)$ and they are willing to use computers as a supplement to other teaching activities (78\%). The remarkable result of only $20 \%$ of the sample that prefer to use computers for distance learning is consistent with Bataineh and Baniabdelrahman (2005) who pointed out that computers can be used as a supplement but cannot fully replace the teacher's job.

Table 2: Overall attitude to ICT's usage

\begin{tabular}{|c|c|c|}
\hline & Yes $\%$ & No $\%$ \\
\hline I prefer to use computers to write assignments for my studies & 93 & 7 \\
\hline I prefer not to use computers to support my studies & 83 & 17 \\
\hline I would prefer to use computers to be taught for a module instead of having a lecturer to teach me & 13 & 87 \\
\hline I would like to use computers as a supplement to other teaching activities & 78 & 22 \\
\hline I would like to communicate with my teacher by e-mail & 64 & 36 \\
\hline I would like to use computers for distance learning & 20 & 80 \\
\hline
\end{tabular}


Regarding the overall computers and internet usage comparing to gender the following table shows the results of the research. The results agree with MorahanMartin (1999) that males are more likely to have internet access to computers off-campus. Specifically, men (70\%) to a larger degree than women $(60 \%)$ use internet offcampus. Almost $98 \%$ of the male students have access to computers off campus in contrary to $78 \%$ of female students who use computers at home. Referring to the students performance no significant differences were found apart form the access to computers off campus. Most students (78\%) that answered yes to the computer access at home passed the module about computers. Silvin-Kachala's (1998) research agreed with the previous results and pointed out that students in technical rich environments score high at the computers modules.

Table 3: Computers and Internet usage compared to gender and performance

\begin{tabular}{l|cc} 
& $\begin{array}{c}\text { Gender } \\
X^{2}\end{array}$ & $\begin{array}{c}\text { Performance } \\
X^{2}\end{array}$ \\
\hline Do you have access to computer off campus & 7,105 & 1,645 \\
\hline Do you have internet access off campus? & 0,993 & 3,727 \\
\hline Do you use your e-mail account off campus? & 6,33 & 1,205 \\
\hline
\end{tabular}

\section{CONCLUSION}

This study found that students of political and social sciences were generally favourable to ICTs usage. Furthermore, male students showed to use ICT's and more often than women.

There are no significant differences between male and female students referring internet and e-mail usage except the computers access off campus. Males seemed to have access to computers off campus more often than women. About students performance, the survey revealed that students that use computers at home tend to score higher than students with no access.

Based on the findings of the research it is recommended for the academic and administrative faculty of the University of Macedonia to motivate students to use ICTs in order to support their studies. This can be achieved from the side of the administrators by facilitating students to have internet access off campus and help them with trouble solving. The academics should integrate ICTs in their teaching methods and persuade students to use computers by writing assignments or searching the internet for information for the modules.

Moreover, the ICTs use is very important for the students after finishing their studies. The ICTs knowledge can help students at their working environments at the future and gives them competitive advantage comparing to others who are not familiar with computers.

\section{REFERENCES}

1. Xin, J. (1999). Computer-Assisted Cooperative Learning in Integrated Classrooms for Students with and without Disabilities. Information Technology in Childhood Education, 61-78.

2. Hoffman, B. (2001). What drives successful technology planning? Journal of Information Technology for Instructor Education, 5(1/2), 43-55

3. Valasidou, A., Sidiropoulos, D., Hatzis, T. and Bousiou-Makridou, D. (2005) Guidelines for the Design and Implementation of E-Learning Programmes, Proceedings of the IADIS International Conference IADIS E-Society 2005, 27 June- 30 June, Qawra, Malta

4. Dorup, J. (2004), Experience and attitudes towards information technology among firstyear medical students in Denmark: Longitudinal questionnaire survey, Journal of Medical Internet Research, 6(1): e10. Retrieved March 10, 2006 from: http://www.jmir.org/2004/1/e10/.

5. Siritongthaworn S., Donyaprueth, K., Dimmitt, N.J and Paul.H (2006) The study of e-learning technology implementation: A preliminary investigation of universities in Thailand, Education and Information Technology, 11, 137-160 
6. Gay, G. and Blades, R. (2005), Information Technology for CXC CSEC, Oxford University Press, Oxford, UK.

7. Schumacher, P. and MorahanMartin, J. (2001), Gender, internet and computer attitudes and Experience, Computers in Human Behaviour, 17(1), 95110

8. Shashaani, L. (1997), Gender differences in computer attitudes and use among college students, Journal of Educational Research Computing Research, 16, 37-51.

9. Bataineh, R.F. and Baniabdelrahman, A.A. (2005), Jordanian EFL students' perceptions of their computer literacy, International Journal of Education and Development using Information and Communication Technology (IJEDICT), 2(2), 35-50.

10. Morahan-Martin, J. (1999). Women and Internet: promise and perils. CyberPsychology \& Behavior, 3(5), 683-696.

11. Ford, N., \& Miller, D. (1996). Gender differences in Internet perceptions and use. Aslib Proceedings, 48(7/8), 183-192.

12. Kulik, J.A. (1994) Meta-analysis study of findings on computer-based instruction. In E.L.Baker and HF. O'Neil Technology Assessment in education and training, Hillsdale, NJ: Lawrence Erlbaum

13. Silvin-Kachala, J. (1998) Report on the effectiveness of technology in schools, 1990-1997. Software Publisher's Association.

\section{NOTES}


NOTES 